\title{
Endangered Apes-Can Their Behaviors Be Used to Index Fear and Disturbance in Anthropogenic Landscapes?
}

\author{
Melissa A. Reisland ${ }^{1}$, Nicholas Malone ${ }^{2}$ and Joanna E. Lambert ${ }^{1,3, *}$ \\ 1 Program in Environmental Studies, University of Colorado Boulder, Boulder, CO 80303, USA; \\ melissa.reisland@colorado.edu \\ 2 Anthropology, School of Social Sciences, University of Auckland, Auckland 1142, New Zealand; \\ n.malone@auckland.ac.nz \\ 3 Program in Environmental Studies and Department of Ecology and Evolution, University of Colorado Boulder, \\ Boulder, CO 80303, USA \\ * Correspondence: joanna.lambert@colorado.edu
}

Citation: Reisland, M.A.; Malone, N.; Lambert, J.E. Endangered Apes-Can Their Behaviors Be Used to Index Fear and Disturbance in Anthropogenic Landscapes? Diversity 2021, 13, 660 . https://doi.org/10.3390/d13120660

Academic Editor: Michael Wink

Received: 25 October 2021

Accepted: 6 December 2021

Published: 11 December 2021

Publisher's Note: MDPI stays neutral with regard to jurisdictional claims in published maps and institutional affiliations.

Copyright: (c) 2021 by the authors. Licensee MDPI, Basel, Switzerland. This article is an open access article distributed under the terms and conditions of the Creative Commons Attribution (CC BY) license (https:// creativecommons.org/licenses/by/ $4.0 /)$.

\begin{abstract}
Behaviors exhibited by prey species towards predators (including humans) can reduce feeding time and increase time spent in vigilance, thereby impacting animal condition and ultimately limit populations, even when actual mortality from predation is low. Here, we test whether behavioral profiles in an endangered ape, Javan gibbons (Hylobates moloch), correspond to varying degrees of human disturbance in a human-impacted sacred forest, Cagar Alam Leuweung Sancang, West Java. Data were collected August 2010-July 2011. Although all groups reacted differently to human presence, overall, gibbons responded by reducing time spent on conspicuous behavior (e.g., vocalizing, feeding, traveling, and social interactions) as the number of humans in the area increased or distance to the nearest human decreased. In addition, gibbon responses to encountering humans were also more like their responses to encountering potential predators than they were to encountering monkeys or other gibbons. These results support the hypothesis that as human presence and encounter rates increase, gibbons alter their behavior in ways consistent with anti-predator behaviors. Assessing how this endangered species responds to human presence is a vital part of their ultimate conservation.
\end{abstract}

Keywords: conservation; predator-prey; gibbon; Hylobates moloch

\section{Introduction}

Low-impact human-wildlife interactions such as wildlife viewing impact animals in many ways, resulting in changes to behavior (e.g., Rangifer tarandus [1]; Rhinoceros unicornis [2]; Ursa actos [3]), habitat use (e.g., Tursiops spp. [4,5]), physiology (e.g., Opisthocomus hoazin [6]), community interactions (e.g., avian scavengers [7]), and population demographics (e.g., Monachus schauinslandi [8]. Among primate species, behavioral shifts in response to human presence are consistent with responses to predation, even in the absence of hunting or trapping [9-15]. Modified behavior can include differences in microhabitat use (e.g., tree canopy strata), suppressed vocalization, and reduced feeding, traveling, and sociality (e.g., Alouatta pigra [16,17]; Callithrix pygmaea [18]; Gorilla gorilla gorilla, [19]; Hylobates lar and Presbytis melalophos $[20,21])$.

In predator-prey systems, population reduction of the prey species is not always caused by mortality per se but by fear of predators [22-32]. Population size can be reduced due to decreased prey fecundity as predator avoidance behaviors lead to missed opportunities to convert resources into offspring [30]. Animals treat predation as a cost of foraging and avoid risky areas and alter foraging strategies when faced with the perceived risk of predation [28-30,33].

The risk effects - or non-consumptive effects (NCE) — of species altering their behaviors to avoid predation are often larger than the direct effect of predation [34]. Thus, it 
follows that human presence alone, even in the absence of human-induced mortality, could impact population dynamics $[12,30,35]$. This effect is magnified in small, isolated populations of mammal species with slow life histories and low intrinsic rates of population growth such as apes and other primates [36-39]. In rapidly changing landscapes, decisions must be made quickly to implement conservation tactics-in many cases this requires proximate indicators of stress or population decline.

Java is among the most densely populated places in the world (1026 people $/ \mathrm{km}^{2}$ [40]). In West Java, where Javan gibbons (Hylobates moloch) are endemic, there is a long history of humans using forest habitat for both resource extraction and cultural reasons, including spiritual visits to the many sacred forests [41]. Java also has a long history of human land use and cultivation, resulting in a few, highly fragmented remaining forests [42]. Over 91\% of the forest cover has been lost $[43,44]$.

The Javan gibbon is classified by the International Union for Conservation of Nature (IUCN) as Endangered [43,45-47]. Currently, the total population estimate for Javan gibbons is 4000-4500 individuals, with most populations living in isolated, unprotected forests in West and Central Java [43,47]. Only 10 populations of gibbons are considered large enough for effective conservation (greater than 100 individuals) [47]. Approximately one fourth to one half of the total population of Javan gibbons lives in small populations fewer than 100 individuals; derived from $[43,47,48]$ - many of these small populations are comprise fewer than 10 individuals $[47,48]$. In addition to the loss of habitat, the illegal trade in Javan gibbons is ongoing and represents a serious risk to the viability of populations throughout their geographic range. Nijman [49] calculated a potential loss of up to $6.86 \%$ per year from the wild population, per year, as a direct result of the illegal trade. Displaced Javan gibbons are found in all stages of the illegal trade network, including private homes, animal markets, and wildlife rescue centers. At the Javan Primates Rehabilitation Centre (JPRC), between 2011-2016 more than 30 Javan gibbons have been confiscated from private ownership [50]. Understanding the dynamics of the illegal hunting, capture and trade of wild Javan gibbons remains the greatest challenge toward facilitating a survival strategy for this endangered species.

We evaluated Javan gibbons' behavioral responses to humans in Cagar Alam Leuweung Sancang (CALS) nature reserve in West Java as a proxy to predict the long-term survival of one population of this endangered species. CALS is a sacred forest-defined as an area of forest that honors a deity, provides sanctuary for spirits, reminds people of their ancestors, and/or protects a sanctified place from exploitation or hunting of animals [51]. In West Java, such forests are frequently visited by local spiritual tourists. We explore whether gibbons respond to the presence of spiritual tourists in a manner consistent with predictions from predator-prey models. Although the gibbons are assumed to be passively habituated to human presence, because of the long history (specific duration unknown) of spiritual tourism in CALS, it is not clear how repeated human exposure affects gibbon behavior [44].

We specifically predicted that if Javan gibbons respond to humans as if they were predators, they will: (PI) decrease time spent on conspicuous behavior (e.g., vocalizing, feeding, traveling, and social interactions) as the number of humans increase; (PII) decrease time spent on conspicuous behavior as the proximity to humans decreases, and (PIII) respond to humans in a manner that is more consistent with their response to predators than non-predator species or conspecifics.

\section{Materials and Methods}

\subsection{Study Site}

CALS is a 2157-hectare reserve located in the province Garut on the south coast of West Java (Map in Figure 1). The reserve was established to protect lowland dipterocarp and mangrove forests and endangered and endemic flora and fauna [44]. Several predator species live within CALS, including leopards (Panthera pardus), eagles and owls (several species), and reticulated pythons (Python reticulatus) [9,44]—all of which were observed 
during this study except for leopards. Humans are known predators of primates though hunting sensu stricto was not witnessed during the study period; however, in a separate study one of us (NM) observed pursuit and capture, presumably for the pet trade. Low levels of human activity occur continually within CALS, mostly in the form of spiritual tourism (defined as tourists to spiritually significant sites); an average of 16.73 people per day enter the forested area of the reserve within the ranges of several gibbon groups [44]. Spiritual tourists at CALS are domestic and almost all from the island of Java. In 2000-2001, large-scale logging occurred within the reserve and as of 2005, 1215.5 hectares remain forested [44]. The reserve is now divided into two fragments, Sancang Timur (East Sancang, approximately $2 \mathrm{~km}^{2}$ ) and Sancang Barat (West Sancang; approximately $4 \mathrm{~km}^{2}$ ), with a minimum of six and two groups of gibbons in each fragment, respectively, for a total population of $<30$ gibbons [44,52]. Gibbons are unable to travel between fragments, and all data reported in the present study are from the eastern fragment (Sancang Timur).
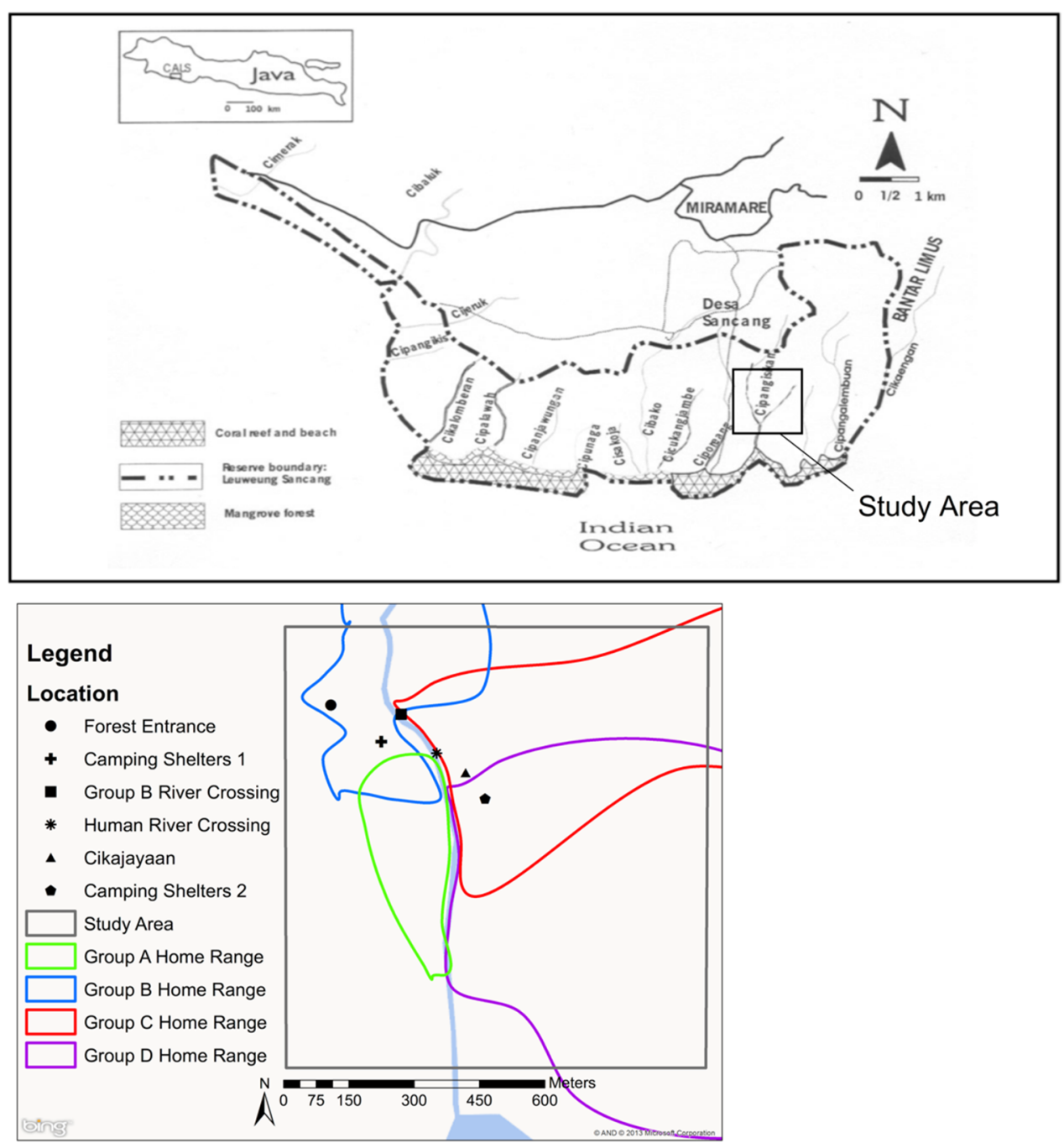

Figure 1. Map of CALS [44] with study area along Cipangisikan River highlighted. Approximate home ranges of study groups are shown on map. Note that home ranges extend beyond study area and home ranges represented outside of study area are estimated. Significant locations within study area are noted on the map.

\subsection{Study Animals}

Within the Sancang Timur fragment, the confirmed six social groupings comprise 15 individual gibbons. Gibbons were located by tracking them from their long calls and searching their home range. Individual identification and assignment to age/sex classes 
was possible for all animals in the focal groups. The age/sex composition of gibbon groups (A-F), as well as salient aspects of their respective home ranges are known (Table 1). Additional assessments for a subset of focal groups (Groups A-C) were conducted in 2012, 2013, and 2016 [53,54]. Group A was once larger $(n=5)$ but was greatly reduced by a reported capture event in 2008 (multiple informants, pers. comm.). The remaining individual, a sub-adult female, persisted within a diminishing range until the last reported sighting of this individual in 2013. For group B, we have documented a history of births $(n=4)$ and infant/juvenile disappearances $(n=2)$. The successive disappearances in 2008 and 2012 are either directly the result of human capture [Wedana Adi Putra, unpublished data] or indirectly related to the increase in invasive human activities within this group's range. Group $\mathrm{C}$ has demonstrated a more stable succession of individuals due to births, maturation and dispersal. Due to limitations in the overall data set caused by the relative inaccessibility of groups $\mathrm{E}$ and $\mathrm{F}$, only data from groups $\mathrm{A}-\mathrm{D}$ are included in the present study. Only adults and independent offspring (i.e., juveniles and subadults) are included in the analyses as the behavioral profiles of infants are considered to be non-independent of their mothers.

Table 1. Gibbons in Sancang Timur.

\begin{tabular}{|c|c|c|c|c|c|c|c|c|}
\hline Group & \# Hum Rank ${ }^{1}$ & Access. Rank ${ }^{2}$ & Gibbon & Age/Sex & \# Scans & Obs. Hrs. & Hum/scan ${ }^{3}$ & SD \\
\hline A & 3 & 2 & Amelia & Adult Female & 1280 & 213.33 & $1.46^{\mathrm{a}}$ & 1.0 \\
\hline \multirow{3}{*}{ B } & \multirow{3}{*}{2} & \multirow{3}{*}{1} & Tono & Adult Male & 1468 & 244.67 & $1.73^{b}$ & 1.66 \\
\hline & & & Tini & Adult Female & 1592 & 265.33 & $1.82^{b}$ & 1.7 \\
\hline & & & $\begin{array}{c}\text { Udian } \\
\text { (dis. } 11 / 10 \text { ) }\end{array}$ & Juvenile & 194 & 32.33 & $2.07^{b}$ & 1.77 \\
\hline \multirow{4}{*}{$\mathrm{C}$} & \multirow{4}{*}{1} & \multirow{4}{*}{3} & Jay & Adult Male & 569 & 94.83 & $3.24^{\mathrm{c}}$ & 3.1 \\
\hline & & & Ann & Adult Female & 663 & 110.5 & $2.94^{\mathrm{C}}$ & 2.88 \\
\hline & & & Cika & Juvenile Male & 591 & 98.5 & $3.10^{\mathrm{c}}$ & 2.83 \\
\hline & & & $\begin{array}{c}\text { Wana } \\
\text { (born 5/11) }\end{array}$ & Infant & $\mathrm{N} / \mathrm{A}$ & $\mathrm{N} / \mathrm{A}$ & $\mathrm{N} / \mathrm{A}$ & $\mathrm{N} / \mathrm{A}$ \\
\hline \multirow{4}{*}{$\mathrm{D}$} & \multirow{4}{*}{3} & \multirow{4}{*}{4} & Sastro & Adult Male & 311 & 51.83 & $1.25^{\mathrm{a}}$ & 0.66 \\
\hline & & & Dian & Adult Female & 477 & 79.5 & $1.32^{\mathrm{a}}$ & 0.78 \\
\hline & & & Wardini & Juvenile Female & 372 & 62 & $1.25^{\mathrm{a}}$ & 0.66 \\
\hline & & & $\begin{array}{c}\text { Bayi } \\
\text { (dis. 3/11) }\end{array}$ & Infant & $\mathrm{N} / \mathrm{A}$ & $\mathrm{N} / \mathrm{A}$ & $\mathrm{N} / \mathrm{A}$ & $\mathrm{N} / \mathrm{A}$ \\
\hline
\end{tabular}

${ }^{1}$ Groups ranked by number of humans they see (most to least). Determined by mean number of humans observed per scan; ${ }^{2}$ Groups ranked by easily humans can access home range (easiest to hardest). Determined by proportion of estimated total home range accessible by humans; ${ }^{3}$ ANOVA with Tukey-Kramer post hoc test. Matching letters indicate values not significantly different $(p<0.05)$.

\subsection{Defining Exposure and Accessibility}

The gibbon groups within CALS experience varying degrees of exposure to humans. We classified exposure by intensity, which was based on the average number of humans encountered and the accessibility of the home range to humans (Table 1 for ranks); we operationalized this measure based on the average number of people (including the observers) to whom the gibbons were exposed per scan (Table 1; ANOVA; $\mathrm{N}=7516, \mathrm{df}=9$, $\mathrm{F}=102.9472, p<0.0001)$. All groups differed from other groups in the average number of people present per scan, except for Amelia, the sole individual from group A, who did not differ from any individual in group $\mathrm{D}$, but individual gibbons within a group did not differ from each other (Tukey-Kramer; $\alpha=0.05$ ). Group $C$ was exposed to the most people per scan. The Cikajayaan waterfall, which is the most sacred site in the forest ([44], Sancang villager, pers. com.]) and thus is the center of most human activity, is located within their home range. Group B was exposed to the second most people per scan. One major sacred site, including shelters where people slept, was located within group B's home range, as well as the foot path leading to Cikajayaan waterfall (concrete steps leading down to the bank of the Cipangisikan river) and the crossing point (raft) of the Cipangisikan river. 
Group D and Amelia were exposed to the fewest people per scan. No group of people larger than seven was ever seen when group D was present, or larger than 11 for Amelia.

We defined accessibility by how easily humans could access the various parts of each gibbon group's home range. This factor was determined by estimating the proportion of each group's home range that contained either sacred sites or paths that would allow humans to encounter gibbons. Home range sizes for the forest are approximately 15 ha. except for group A [44]. Group B's home range was the most accessible, as there was only one section of the range (across the Cipangisikan river) where humans could not easily access. Group A's home range was the second most accessible. This is largely because the home range was very small (6.25 ha. in 2005 [44]), so that its two main points of access (Cipangisikan river crossing site and local fishing site) represent a significant proportion of the home range. Although the Cikajayaan waterfall was the most populated area, it and the surrounding areas were the only part of group C's home range that were easily accessible to humans, making it the third most accessible. Group D's home range was the least accessible because although it contained one small sacred site, the paths and site were not often used and only accounted for a small part of the home range.

\subsection{Data Collection}

Behavioral data were collected from August 2010 until June 2011. Data collection began between 0545 and 0615 every morning and continued until 1630 or until the gibbons moved into their sleeping trees and ceased activity. MAR trained all four assistants on data collection. Due to the topography of CALS, data were collected opportunistically when groups were visible. All behavioral data were collected on PDAs using the CyberTracker data collection program [55]. Data were then uploaded into Microsoft Excel and then imported into JMP Statistical Software Version 9.0 [JMPTM , Cary, NC, USA] for analysis. This researcher complied with the protocols of the Institutional Animal Care and Use Committee of the Research Animal Resource Center of the University of Wisconsin, Madison, with the legal requirements of the government of Indonesia, and with the American Society of Primatologists Ethical Treatment of Non-human Primates.

We conducted instantaneous 10-min scan samples throughout the day [56]. Every day, each researcher collected data from a different study group, and no two researchers conducted scans from the same location (when more than one researcher was in the same place, only one person collected scan data). Data collection began for each researcher when he or she arrived in the home range of the designated group. When gibbons were absent, we recorded the number of each type of human visible. Humans were defined as either a "researcher" (MAR and field assistants), "local" (citizen of Sancang village, typically not in the forest for spiritual purposes), or "spiritual tourist" (person who traveled to visit the forest, typically for spiritual purposes). When gibbons were present, along with the information stated above, we also recorded the gibbon group(s) visible. For every independent gibbon visible, we recorded its identity, behavior, and Euclidean distance from nearest humans ( $<25 \mathrm{~m}, 25-50 \mathrm{~m}, 50-75 \mathrm{~m}, 75-100 \mathrm{~m},>100 \mathrm{~m})$.

We also collected 10-min continuous focal animal samples between scans on one systematically chosen gibbon [56]. The first focal individual was chosen randomly, and after that, focal samples were rotated among visible group members so no animal was sampled two times in a row. During the focal sample, we recorded any encounters with humans, conspecifics (by group), other primates (colobines Trachypithecus auratus mauritius and Presbytis comata, or macaques Macaca fascicularis), or predators (cats, primarily Panthera pardus melas; snakes, primarily Python reticulatus, and raptors). Encounters were defined as when the encountered individual (see above) came into the visual range of the focal gibbon. Encountered individuals were not present at the beginning of the focal sample but arrived during the focal sample because we were interested in reactions. We recorded any movement in the canopy of the focal animal immediately following the encounter as either higher or lower (vertical movement) and as either closer to or farther away from the encountered subject (horizontal movement). Since predator encounters are rare, we 
also recorded all occurrence ad libitum [56] sampling of any encounters with predators we observed. During this study, we only observed encounters with raptors as predators.

\subsection{Analysis}

Since the behavior of gibbons within a group are not independent of each other (e.g., individuals in a group all resting at same time), gibbons in the same group were combined for all analyses. The one exception to this pooling of behavioral data was when females did long call vocalizations. Additionally, all social behaviors (allogroom, groom recipient, play) were grouped together as 'social' and all very rare behaviors (aggression, vigilance, drink, autogroom) were grouped as 'other.' Forest physiognomy and topography made all day follows unfeasible, and as a result not all groups and times were sampled equally. We recognize that vocalization behavior was over-sampled; vocalizations could almost always be detected, even at very far distances, and were explicitly used as a way to locate the group. To control for this oversampling, we only analyzed those vocalization bouts in which the group was visible. This was not possible for Group A, comprising only one individual. For Group A we thus excluded data from 100+ $\mathrm{m}$ away-the point at which no other behaviors beyond vocalization could be detected due to distance.

We defined Conspicuous behaviors as those behaviors resulting in a gibbon being easier to detect, either visually (including traveling and non-traveling movement) or auditorily (e.g., vocalizing, feeding, traveling, and social behaviors). Inconspicuous behaviors were defined as those behaviors that do not engender gibbons more detectable (e.g., resting/inactive, sleeping, out of sight). While sleeping is inconspicuous, it is not a predator avoidance behavior [9]. However, we include it here because sleep in this context typically occurred during the gibbons' active period as short rests (not during their nighttime sleeping bout) and could therefore be easily disrupted by activities in the forest, while on its own still rendered the gibbons harder to detect. We considered gibbons positioned 0-25 or $25-50 \mathrm{~m}$ from humans as being conspicuous and gibbons positioned at 75-100 m, or $100+m$ away from humans as being inconspicuous. We used a starting alpha of $p<0.05$ to define significance.

We used separate logistic regression analyses to detect whether the group changed its behavior (response variable) or distance from the nearest human(s) (response variable) as the number of people present (independent variable) increased. Only scans with at least one gibbon present were included in the analysis. Due to the rare occurrence of spiritual tourist groups larger than 15, all analyses were limited to group sizes of 15 or less. If the logistic regression for all behaviors or distances was significant, we used individual logistic regression to test each behaviors/distance separately, where the presence and absence of the behavior was coded as 1 and 0 respectively. Some behaviors occurred infrequently to such a degree that the analyses performed could not detect any change, so these behaviors were not independently analyzed. Therefore, only feed, not visible, sleep, inactive, travel, vocalize were tested. Due to repeated sampling, $p$ values were adjusted with a modified Bonferroni correction [57].

Likelihood ratio chi-square analyses were used to determine if a gibbon group changed its behavior at various distances away from one human. These analyses were limited to observations where the number of people present equaled one to control for the difference in mean number of people per scan for the different gibbons. For all $\chi^{2}$ analyses where the dependent variable differed from the expected values generated from $\chi^{2}$ probabilities, we used the individual cell $\chi^{2}$ values to determine which specific cells were deviating from expectations. Individual cell $\chi^{2}$ values higher than $3.841(p=0.05$ for $\mathrm{df}=1)$ differed significantly from the expected value.

Because encounter rates between human visitors and gibbons were low, we grouped all gibbons together for all analyses comparing different types of encounters. We used likelihood ratio $\chi^{2}$ analyses to compare movement in the canopy following an encounter for all encounter types. 


\section{Results}

We analyzed a total of $668.66 \mathrm{~h}$ of behavioral data from direct observation. The number of hours each individual gibbon was observed is found in Table 1. Here, we address each prediction (PI-PIII) as outlined in the introduction.

\subsection{Test of Prediction I: If Javan Gibbons Treat Humans as Predators, Gibbon Groups Will Decrease Time Spent on Conspicuous Behavior as the Number of Humans Increase \\ 3.1.1. Behavior by Number of Humans}

Our prediction was partially supported by analysis of gibbon behavior by number of humans present. As the number of humans increased, members of group B were less likely to feed, and they were more likely to sleep (Figure 2; $\mathrm{N}=2985, \chi^{2}=70.325, \mathrm{df}=8$, $p<0.0001$ ), which supported our predictions. Similarly, group $C$ decreased time spent vocalizing. However, contrary to our predictions, members of group $C$ increased time spent feeding and decreased time spent not visible and sleeping (Figure 2; $N=1602, \chi^{2}=72.829$, $\mathrm{df}=8, p<0.0001$ ). Also contrary to our predictions, were groups A and D. Amelia, the solitary group A female, did not change her behavior as the number of people present changed (Figure 2; $\mathrm{N}=1280, \chi^{2}=11.893, \mathrm{df}=8, p=0.1561$ ), and as the number of people increased, group D individuals were more likely to feed (Figure 2; $\mathrm{N}=992, \chi^{2}=17.758$, $\mathrm{df}=8, p=0.0231$.

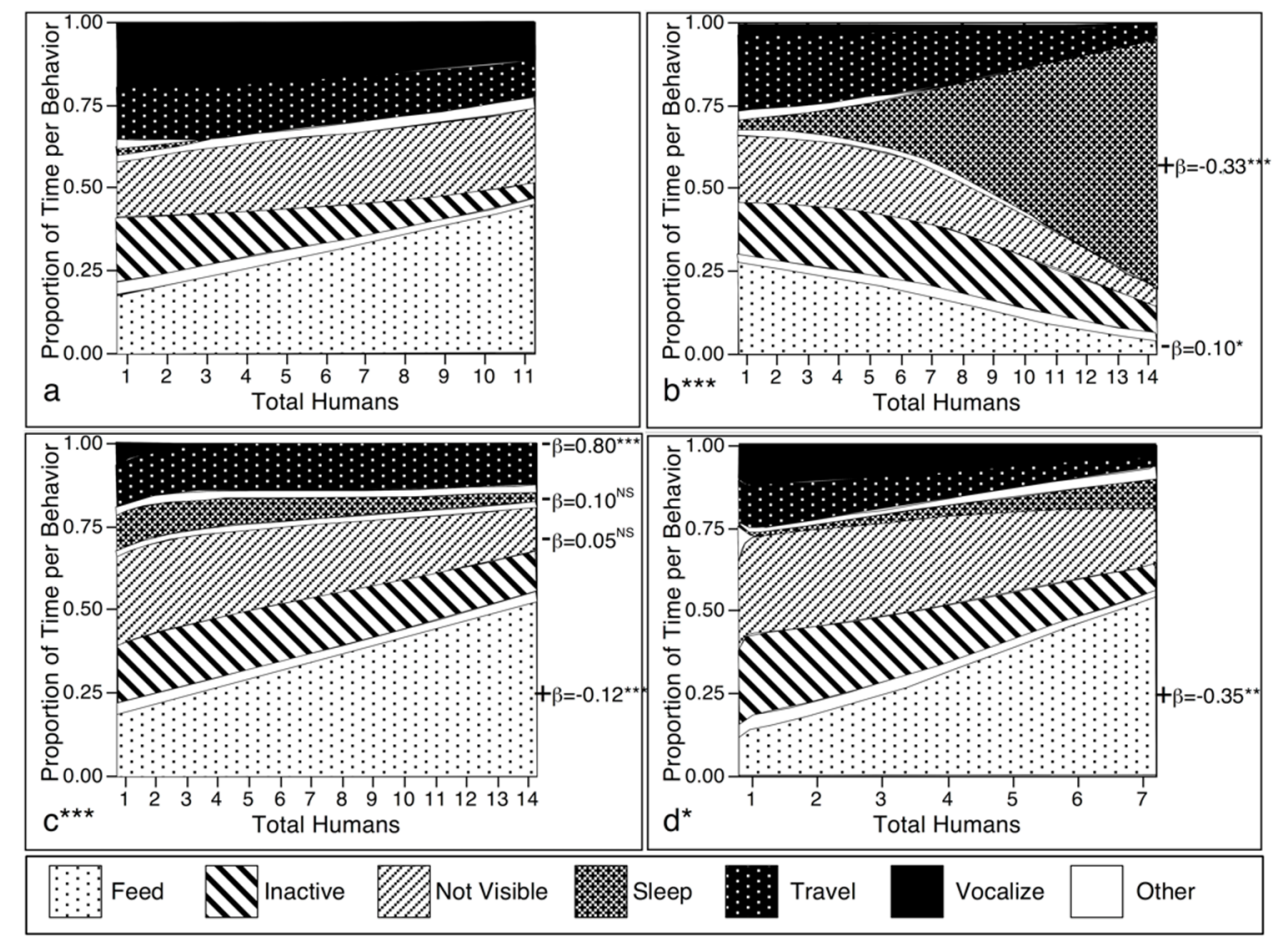

Figure 2. Behaviors at varying numbers of humans present for (a) Group A; (b) Group B; (c) Group C; and (d) Group D. Some behaviors occurred infrequently to such a degree that the analyses performed could not detect any change, so these behaviors were not independently analyzed Only behaviors that occurred frequently enough for an affect to be detected are shown. The area between the curves predicts the proportion of time the gibbon spends on each behavior. Behaviors correspond to key at bottom of the figure. Individual behaviors that changed significantly with changing numbers of humans are indicated with either a + (behavior increases in frequency as number of humans increase) or a - (behavior decreases in frequency as number of humans increases). For $p$ values, NS: $<0.1$, *: $<0.05,{ }^{* *}:<0.01,{ }^{* * *}:<0.001$.

\subsubsection{Distance by Number of Humans}

Our prediction was mostly supported by analysis of gibbon distance from humans by number of humans present. We analyzed the effect of total number of humans on gibbon 
distance from humans. The results from group B once again supported our prediction. As the number of people increased, they were less likely to be $0-25 \mathrm{~m}$ away and more likely to be $75-100 \mathrm{~m}$ away (Figure $3 ; \mathrm{N}=2985, \chi^{2}=17.915, \mathrm{df}=4, p=0.0013$ ). The result from groups $C$ and $D$ also partially supported our prediction. As the number of people increased group $C$ individuals were less likely to be $50-75 \mathrm{~m}$ away (Figure $3 ; \mathrm{N}=1593, \chi^{2}=13.21$, $\mathrm{df}=4, p=0.0103$ ). Members of group $\mathrm{D}$ were less likely to be $0-25 \mathrm{~m}$ away and $75-100$ $\mathrm{m}$ away, and more likely to be 25-50 $\mathrm{m}$ and 50-75 $\mathrm{m}$ away (Figure $3 ; \mathrm{N}=992, \chi^{2}=22.756$, $\mathrm{df}=4, p<0.0001)$.

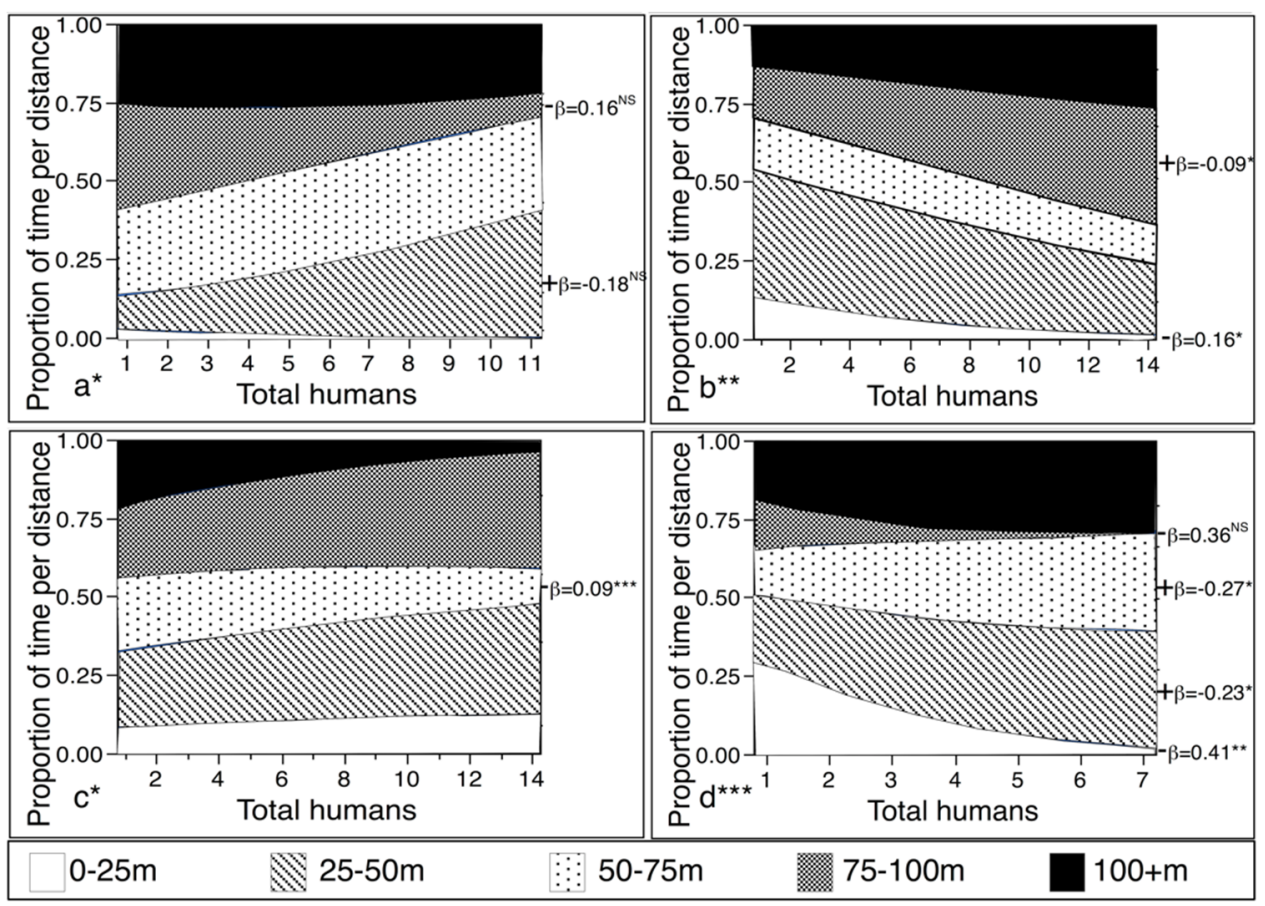

Figure 3. Distance from humans at varying numbers of humans present for (a) Group A; (b) Group B; (c) Group C; and (d) Group D. The area between the curves predicts the proportion of time the gibbon spends at each distance. Distances correspond to the key at the bottom of the figure. Individual distances that changed significantly with changing numbers of humans are indicated with either $\mathrm{a}+$ (time at distance increases in frequency as number of humans increase) or a - (time at distance decreases in frequency as number of humans increases). For $p$ values, NS: $<0.1, *:<0.05,{ }^{* *}:<0.01$, $* * *:<0.001$.

Group A (Amelia) behaved contrary to our predictions. As the number of people per scan increased, Amelia was more likely to be $25-50 \mathrm{~m}$ away and less likely to be $75-100 \mathrm{~m}$ away from the nearest human(s) (Figure 3; $\mathrm{N}=1280, \chi^{2}=10.505, \mathrm{df}=4, p=0.0327$ ).

3.2. Prediction II: If Javan Gibbons Treat Humans as Predators, Gibbon Groups will Decrease Time Spent on Conspicuous Behavior as the Proximity to Humans Decreases

This prediction was mostly supported. All gibbon groups altered behavior as distance from one human researcher changed (A: $\mathrm{N}=692, \chi^{2}=81.563, \mathrm{df}=21, p<0.0001 ; \mathrm{B}: \mathrm{N}=1713$, $\chi^{2}=258.712, \mathrm{df}=32, p<0.0001 ; \mathrm{C}: \mathrm{N}=536, \chi^{2}=157.649, \mathrm{df}=32, p<0.0001 ; \mathrm{D}: \mathrm{N}=790$, $\left.\chi^{2}=186.84, \mathrm{df}=32, p<0.0001\right)$. As predicted, all gibbon groups vocalized less than expected by $\chi^{2}$ probabilities assuming distance from humans had no effect on behavior at close distances and /or more than expected at far distances (Table 2). Also supporting our predictions, group B slept and were inactive less than expected at 100+ $\mathrm{m}$ away and traveled less than expected at $0-25 \mathrm{~m}$ away. Group $\mathrm{C}$ was inactive more than expected at 0-25 $\mathrm{m}$ away and less than expected when they were $100+\mathrm{m}$ away. Group D were inactive more than expected at $0-25 \mathrm{~m}$ away and less than expected at 50-75 $\mathrm{m}$ and $100+\mathrm{m}$ away. They traveled less than expected at 0-25 m away (Table 2). 
Table 2. Behavioral changes at varying distances from one human researcher.

\begin{tabular}{|c|c|c|c|c|c|}
\hline Group & Behavior & Distance & $\begin{array}{c}\text { Difference } \\
\text { from Expected a }\end{array}$ & $\mathbf{N}$ & Cell $\chi^{2}$ \\
\hline \multirow{5}{*}{$\begin{array}{c}A \\
N=692\end{array}$} & \multirow{3}{*}{ Feed } & $0-25 \mathrm{~m}$ & + & 14 & 12.50 \\
\hline & & $50-75 \mathrm{~m}$ & + & 80 & 7.09 \\
\hline & & $75-100 \mathrm{~m}$ & - & 40 & 16.27 \\
\hline & \multirow{2}{*}{ Vocalize } & $25-50 \mathrm{~m}$ & - & 3 & 6.45 \\
\hline & & $75-100 \mathrm{~m}$ & + & 62 & 12.43 \\
\hline \multirow{15}{*}{$\begin{array}{c}\mathrm{B} \\
\mathrm{N}=1713\end{array}$} & \multirow{4}{*}{ Feed } & $0-25 \mathrm{~m}$ & + & 121 & 39.95 \\
\hline & & $50-75 \mathrm{~m}$ & - & 52 & 5.92 \\
\hline & & $75-100 \mathrm{~m}$ & - & 41 & 10.14 \\
\hline & & $100+\mathrm{m}$ & - & 14 & 13.99 \\
\hline & \multirow{4}{*}{ Not Visible } & $0-25 \mathrm{~m}$ & - & 20 & 22.11 \\
\hline & & $25-50 \mathrm{~m}$ & - & 129 & 5.07 \\
\hline & & $50-75 \mathrm{~m}$ & + & 77 & 6.14 \\
\hline & & $100+m$ & + & 64 & 41.24 \\
\hline & Sleep & $100+m$ & - & 0 & 4.89 \\
\hline & Inactive & $100+m$ & - & 8 & 10.19 \\
\hline & Travel & $0-25 \mathrm{~m}$ & - & 42 & 6.43 \\
\hline & Social & $50-75 \mathrm{~m}$ & - & 1 & 4.10 \\
\hline & \multirow{2}{*}{ Vocalize } & $25-50 \mathrm{~m}$ & - & 15 & 8.73 \\
\hline & & $100+\mathrm{m}$ & + & 19 & 26.98 \\
\hline & Other & $0-25$ & + & 8 & 3.89 \\
\hline \multirow{8}{*}{$\begin{array}{c}C \\
N=536\end{array}$} & Feed & $100+m$ & - & 0 & 11.57 \\
\hline & \multirow{2}{*}{ Not Visible } & $0-25 \mathrm{~m}$ & - & 17 & 6.73 \\
\hline & & $100+m$ & + & 32 & 7.55 \\
\hline & \multirow{2}{*}{ Sleep } & $50-75 \mathrm{~m}$ & + & 17 & 7.46 \\
\hline & & $100+\mathrm{m}$ & - & 0 & 4.16 \\
\hline & \multirow{2}{*}{ Inactive } & $0-25 \mathrm{~m}$ & + & 39 & 25.51 \\
\hline & & $100+m$ & - & 0 & 11.10 \\
\hline & Vocalize & $100+m$ & + & 17 & 45.53 \\
\hline \multirow{13}{*}{$\begin{array}{c}\mathrm{D} \\
\mathrm{N}=790\end{array}$} & \multirow{2}{*}{ Feed } & $0-25 \mathrm{~m}$ & + & 57 & 13.53 \\
\hline & & $50-75 \mathrm{~m}$ & - & 11 & 4.64 \\
\hline & \multirow{2}{*}{ Not Visible } & $0-25 \mathrm{~m}$ & - & 45 & 12.76 \\
\hline & & $50-75 \mathrm{~m}$ & + & 67 & 10.62 \\
\hline & Sleep & $50-75 \mathrm{~m}$ & + & 3 & 6.54 \\
\hline & \multirow{3}{*}{ Inactive } & $0-25 \mathrm{~m}$ & + & 85 & 10.06 \\
\hline & & $50-75 \mathrm{~m}$ & - & 21 & 6.08 \\
\hline & & $100+\mathrm{m}$ & - & 1 & 17.22 \\
\hline & Travel & $0-25 \mathrm{~m}$ & - & 24 & 3.90 \\
\hline & \multirow{2}{*}{ Vocalize } & $0-25 \mathrm{~m}$ & - & 17 & 6.77 \\
\hline & & $100+m$ & + & 34 & 57.09 \\
\hline & Social & $0-25 \mathrm{~m}$ & + & 6 & 8.52 \\
\hline & Other & $0-25 \mathrm{~m}$ & + & 7 & 9.94 \\
\hline
\end{tabular}

a Difference column signifies if the group performed the behavior more (+) or less (-) than expected based on $\chi^{2}$ probabilities assuming distance has not effect on behavior. Only behaviors that differed from expected frequency of occurrence (cell $\chi^{2}$ value over $3.841(p=0.05$ for $\mathrm{df}=1)$ ) are reported.

However, gibbon feeding behavior was contrary to our predictions. Groups A, B, and $D$ all fed more than expected by $\chi^{2}$ probabilities assuming distance from humans had no effect on behavior at close distances while groups A, B, and C all fed less than expected 
at far distances (Table 2). Also contrary to our prediction, groups B, C, and D were out of view less than expected at close distances and more than expected at far distances, but this can be explained by gibbons being easier to observe at close distances (Table 2).

3.3. Prediction III: If Javan Gibbons Treat Humans as Predators, Gibbon Groups Will Respond to Humans More Similarly to How They Respond Other Predators Than How They Respond to Other Non-Predator Primate Species (Conspecifics, Monkey Species)

This prediction was supported. We observed 538 encounters, 394 encounters with humans, 93 encounters with monkeys, 30 encounters with gibbons from other groups, and 21 encounters with predators (raptors). Gibbons moved horizontally both towards $\left(\mathrm{N}=6, \chi^{2}=7.94\right)$ and away from other gibbons $\left(\mathrm{N}=14, \chi^{2}=9.19\right)$ more than expected by $\chi^{2}$ probabilities assuming that encounter type did not affect gibbon movement. They also moved away from monkeys more than expected $\left(\mathrm{N}=32, \chi^{2}=7.67\right)$ and away from humans less than expected $\left(\mathrm{N}=65, \chi^{2}=4.09\right)$. They maintained their horizontal position less than expected when encountering other gibbons $\left(\mathrm{N}=10, \chi^{2}=6.26\right)$ and monkeys $\left(\mathrm{N}=50, \chi^{2}=4.34\right)$ (Figure $\left.4 ; \mathrm{N}=538, \chi^{2}=17.201, \mathrm{df}=6, p<0.0001\right)$. For all encounter types, gibbons moved away from the encountered individual(s) more often than they moved towards it, however for both humans and predators, the vast majority of the gibbons' responses were to not change their horizontal position, whereas with other gibbons and monkeys they did change their horizontal position a much larger proportion of the time.

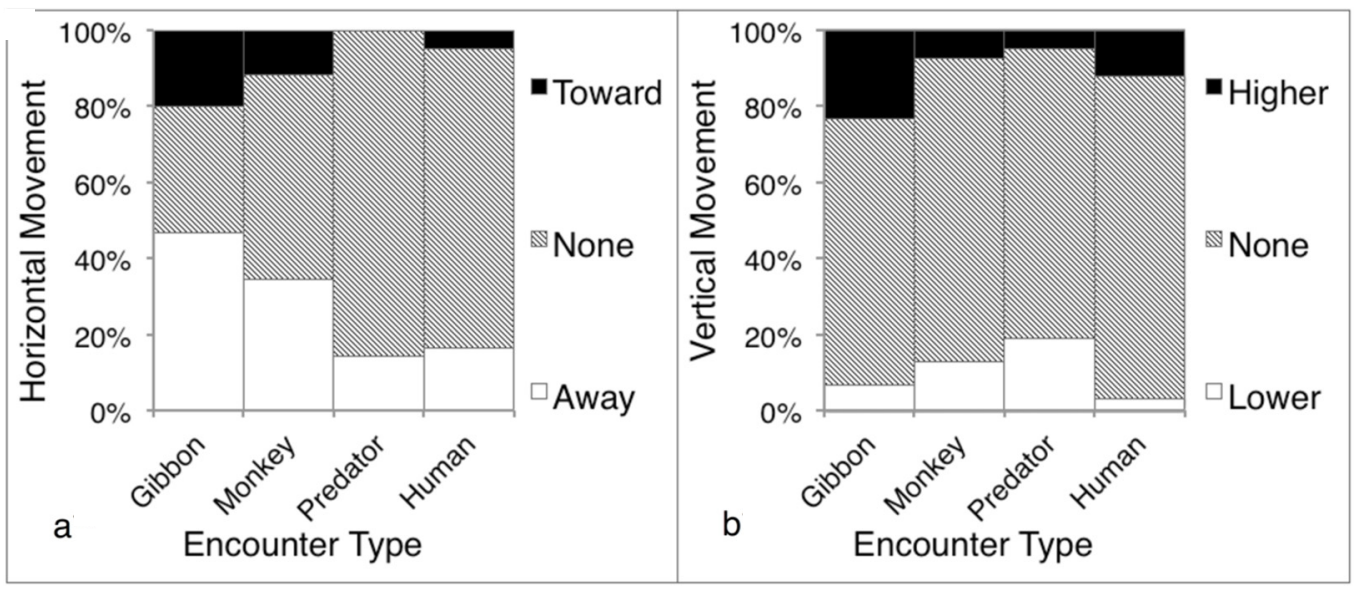

Figure 4. (a) Horizontal movement and (b) Vertical movement in the canopy by encounter type (gibbon, human, monkey, predator). Labels correspond to colors on the key on the right.

For all encounter types, gibbons generally did not change their vertical position in the canopy, but they moved lower in the canopy less than expected by $\chi^{2}$ probabilities assuming that encounter type did not affect gibbon movement when encountering humans $\left(\mathrm{N}=12, \chi^{2}=4.52\right)$ and more than expected when encountering monkeys $\left(\mathrm{N}=12, \chi^{2}=8.95\right)$ and avian predators $\left(\mathrm{N}=4, \chi^{2}=6.83\right)$. Upon encountering humans, gibbons most often did not change their vertical position $(\mathrm{N}=334)$. They moved higher in the canopy $(\mathrm{N}=48)$ more often than they moved lower in the canopy $(\mathrm{N}=12)$, but this difference was not significant (Figure 4; $\mathrm{N}=538 \chi^{2}=27.176, \mathrm{df}=6, p=0.0001$ ).

\section{Discussion}

In this research we hypothesized that Javan gibbons would respond to humans in a manner consistent with their behavioral responses to predators. Specifically, we predicted that gibbons would increase time engaged in inconspicuous behaviors and decrease time engaged in conspicuous behaviors as either the number of humans increased (Prediction I) or the proximity to humans decreased (Prediction II). We also predicted the gibbons would respond to humans in a manner that is more consistent with their response to predators 
than non-predator species or conspecifics (Prediction III). We found varying support for our predications.

\subsection{Response to Human Group Size}

Group B was most sensitive to the number of people present, with members behaving more inconspicuously and positioning themselves farther from human groups as the number of people present increased. Of all the groups, group B had the most accessible home range (i.e., humans could access the largest portion of it relative to other groups' home ranges), which is consistent with our hypothesis that the constant risk of human exposure may result in more pronounced behavioral changes. Additionally, because of the accessibility of group B's home range, humans were on average $52 \mathrm{~m}$ away from them, which is second closest to group D (46 m away). For group B, this high accessibility manifests as increased sensitivity to changes in human group size.

Home range accessibility seemed to affect gibbons' response to larger groups more than average number of people per scan, as group $C$ was less sensitive to changes in group size despite seeing more people per scan on average. They also were observed farther away than group B $(60 \mathrm{~m})$ on average. In fact, group C increased feeding (a conspicuous behavior) as the number of people increased. Why this was the case is not clear. One likely explanation is the number of preferred feeding trees in a high human traffic area in group C's home range. Most of the observations of group $C$ were from near Cikajayaan because many other parts of group C's home range were inaccessible due to sheer cliffs and thick vegetation. However, they came to Cikajayaan regularly when the trees in the area were fruiting. Humans also came to this spot variably depending on season; during some time periods it was not uncommon for over 20 people to be at Cikajayaan, and during other times the area would be almost empty. It is possible that the fruit trees here represent a crucial part of group C's food intake when they are in season, and that this season corresponds to times of high usage by visitors. However, data on plant phenology in the area would need to be collected to confirm this hypothesis.

It may be possible to explain group C's results as a consequence of increased habituation or tolerance to large groups of people, as group $C$ has historically had many people in their home range (pers comm $[35,58]$ ). However, if habituation were the only factor, we would have expected groups $\mathrm{A}$ and $\mathrm{D}$, having on average the lowest number of people per scan, to be more sensitive to increasing group size, but this was not the case. Like group C, group D increased time spent feeding as the number of people increased, whereas group A (Amelia) did not alter her behavior with changing human group sizes. Amelia's behaviors are likely due to her changing home range use. Early in the study, Amelia occasionally occupied the most northern part of her home range, near the site where visitors cross the Cipangisikan River to go to Cikajayaan. Thus, most of her encounters with larger groups are from this spot, and at this location (North River), Amelia was also easily accessible to humans. Amelia appeared unable to defend her territory from encroachment by group B [pers. obs.]. Her shrinking home range meant she might have had to exploit areas close to humans that other gibbon groups would avoid [59]. She was the only gibbon who consistently acted contrary to predictions for both behavior and distance to humans as number of humans increased. However, as she was pushed farther south into her home range, she spent less time at this easily accessible area, which resulted in her being observed from the farthest average distance from humans $(76 \mathrm{~m})$.

\subsection{Response to Distance to Nearest Human}

Although not all groups consistently altered their behaviors in response to changes in human group size, they were all consistently affected by distance from the nearest human. Increased number of people present resulted in groups B, C, and D spending either more time at farther distances or less time at closer distances to humans.

All gibbon groups were also sensitive to their distance from one human researcher. Most behavioral alterations were consistent with our predictions; group B and D gibbons 
traveled less when close to the researcher, and group $C$ and $D$ gibbons were more often inactive when close to the researcher. However, groups A, B, and D all fed more when they were close to the researcher, but this may be caused by either (1) fruits being located on lower trees or branches than the gibbons prefer for travel and rest or (2) feeding being more readily observable at close distances. As feeding is a relatively conspicuous behavior, it is unlikely it was missed at other distances. Thus, in general gibbons seem to be more sensitive to the distance from humans than they are to the number of humans present. Distance sensitivity has also been reported in habituated gorillas exposed to spiritual tourist groups [19].

Our most striking result is that all groups vocalized more frequently when farther away from the researcher and less frequently when researchers were in closer proximity (Table 2). Vocalizations are the most conspicuous (i.e., easily detectable) behavior in the Javan gibbon behavioral repertoire [60]. Unlike most other gibbon species, Javan gibbons do not duet. Female gibbons often perform the great calls solitarily, occasionally accompanied by juveniles of either sex [61]. Female song bouts usually occur in the crown of a tree with a freestanding crown. The great calls are highly conspicuous because their sound travels for $1500 \mathrm{~m}$ [60] and during the crescendo of the great call, the female quickly brachiates to nearby branches $[9,60]$ though not all populations do this [61]. Suppressing vocalizations makes gibbons less detectable, and human activity is known to result in vocalization suppression in gibbons $[11,20]$ and other primates $[10,18]$.

Most vocalizations for almost every gibbon were recorded from greater than $100 \mathrm{~m}$ away. Preference for vocalizing high in the canopy $[9,60]$ may partially explain why so few vocalizations were observed at close distances. However, the canopy in Sancang was approximately $50 \mathrm{~m}$ high, so we would expect to observe a high proportion of vocalizations at $50-75 \mathrm{~m}$ or $75-100 \mathrm{~m}$ away. Alternatively, because vocalizations are the most conspicuous behavior, they could be detected at any distance, whereas other behaviors were difficult to see when the gibbons were more than $100 \mathrm{~m}$ away. This resulted in an under sampling of non-vocalizing behaviors at far distances. However, gibbons still vocalized proportionally more at far distances even after oversampled vocalizations were removed, and total numbers of vocalizations observed were much higher at over $100 \mathrm{~m}$ away from the researcher when all vocalizations were included. A final confounding factor to this observation is that as each distance class increases, more area is observable, so it may be expected that more observations of vocalizations would occur at greater distances, especially since vocalizations could be so easily detected. However, while this may explain some of the skew in vocalization observations, it is unlikely to fully explain the pattern observed. If increased observable area at increased distances did lead to more observations at these distances, we would expect to observe more of all behaviors at farther distances and more total observations at farther distances, but this is not the case for any other behavior, including other conspicuous behaviors or for total number of observations. This may be due to the ease of observing vocalizations relative to other behaviors, but analyses controlled for this phenomenon by eliminating instances where vocalizations could be observed but other behaviors could not easily be observed (see above). Upon locating gibbons, we positioned ourselves in a way to most easily observe their behavior (aided by binoculars), so that we could detect all behaviors from where we were located, not just vocalizations. Thus, the number of scans where vocalizations were only observed because of their highly conspicuous nature was effectively minimized. Further support of vocalization suppression comes from group $\mathrm{D}$, who vocalized more than the other gibbon groups, and had the least human exposure. Based on our results and the propensity for Javan gibbons to employ inconspicuousness as an anti-predator behavior, we suggest that the gibbons in this forest suppress their vocalizations when human groups are nearby to avoid detection by these groups.

Vocalization suppression has conservation implications for gibbons because the purposes of song bouts include group spacing, defense of resources, mate attraction, and strengthening or advertisement of the pair bond [62-71]. Thus, suppressed vocalizations 
could result in reduced strength of pair bonds, reduced ability to find mates, reduced ability to defend territories, and increased intergroup conflict. We also proposed that gibbons' movement in the canopy upon encountering humans will be more similar to their response to predators than their response to monkeys or other gibbons (Prediction III). This hypothesis was supported. The most common response to humans and predators was for gibbons to not move at all, but when they did move, to move away from the human/predator (higher for humans and lower for avian predators). Upon encountering other gibbons or monkeys, gibbons were much more likely to move in general and also more likely to move toward them than they were humans or predators. Additionally, the large portion of the time gibbons respond to humans and avian predators by not changing their canopy position is expected because gibbons are most likely to employ inconspicuousness as an anti-predator behavior for avian predators and humans [9].

\subsection{Conservation Implications}

Community based conservation projects such as low impact nature-based tourism (as in Sancang) or ecotourism, are becoming popular conservation strategies in developing nations [72]. Such strategies can have both positive and negative impact on the local communities and the natural area and wildlife [16,73-78]. Tourism can cause primates to alter time budgets, suppress vocalizations, and can interfere with primate reproduction and feeding [16]. However, the effects of low-impact human exposure on animal behavior are only starting to be understood [79], and remain unknown for many species.

Kappeler [9] describes the general anti-predation strategy of Javan gibbons as predator avoidance. Predator avoidance behavior for Javan gibbons includes utilizing cryptic behavior (remaining still, avoiding conspicuous behaviors such as feeding and traveling), and increasing vigilance. Based on this description, Javan gibbons at CALS reacted to humans in ways that are consistent with gibbon and primate anti-predator behavior through increased cryptic behavior. Unsurprisingly, gibbons were most affected by humans when they had a highly accessible home range and when they were exposed to larger groups of spiritual tourists. Constant human presence also seems to affect gibbons more than periodic exposure. In a complementary study using GIS analysis, Reisland and Lambert [80] found group B to be more sensitive to the presence of humans than group C, occupying their range in non-random patterns to avoid humans which they may perceive as risky. In contrast, group C's spatial patterning did not support the hypothesis that humans were a risk to be avoided; this group was just as likely to be observed within areas of intensifying human presence as in areas without humans [80].

Though behavioral changes themselves do not directly inform us about population growth, increased anti-predator behavior has been demonstrated to result in reduced growth rates for populations $[25,30,34]$. This is because the threat of predation causes prey species to forage less efficiently than in the absence of predators due to increased time spent on predator avoidance and vigilance and decreased time spent in risky areas or on conspicuous behaviors [30,34]. While the behavioral changes observed in Javan gibbons seem minor, even small decreases in growth rate can be detrimental to such a small population of animals [39]. Javan gibbons are endangered, and most populations are both small and in decline. The good news is that behaviors measured here suggest that Javan gibbons possess the resilience and behavioral flexibility to deal with human "predators" and may be able to adapt to the low levels of disturbance that occur within CALS. Because of this observed behavioral flexibility and the lack of long-term data at this site, the direct fitness consequences to gibbons are not yet known, but the potential fitness implications of nature-based tourism warrant further study.

This study is not meant to represent the population level effects of human presence on all primates, or even all Javan gibbons. The Javan gibbon population in CALS is very small ( $<30$ individuals), though it represents the largest population of lowland Javan gibbons outside of Ujung Kulon National Park [44]. Furthermore, the gibbon population size in the forest has remained relatively stable over the course of the past decade $[53,54]$. In a 
comparison of census population $(\mathrm{N})$ and effective population sizes $(\mathrm{Ne})$ over time for a subset of gibbon groups within CALS (groups A, B and C), population growth associated with the survival and maturation of offspring within Group $C$ were offset by the loss of individuals from groups A and B [54] (See Section 2.2 Study Animals). All of the gibbons in the forest are habituated to human presence due to years of human spiritual use, but no groups were ever actively habituated. Therefore, different and opposing responses to humans is expected for these groups because in some parts of the reserve humans represent both a real and a perceived risk to gibbons, whereas elsewhere, the presence of spiritual sites and practices seems to limit detrimental human activities to the potential advantage to gibbon population health. It is our hope that this study can serve as a case study of the impact of tourists on non-human primates and can be applied to similar sites that employ nature-based tourism or ecotourism as a conservation strategy. Our results support the hypothesis that gibbons alter their behaviors in response to human presence and encounter rates, and the degree in which they engaged in anti-predator behavior varies based on the context of the interactions These behavioral alterations must be considered when evaluating the conservation potential of Javan gibbon populations.

Author Contributions: Conceptualization, M.A.R. and J.E.L.; methodology, M.A.R. and J.E.L.; formal analysis, M.A.R.; field investigation, M.A.R. and N.M.; resources, J.E.L.; data curation, M.A.R.; writing—original draft preparation, M.A.R.; writing—review and editing, M.A.R., J.E.L. and N.M.; supervision, J.E.L.; project administration, M.A.R.; funding acquisition, M.A.R. All authors have read and agreed to the published version of the manuscript.

Funding: This research was funded by a Fulbright IIE Fellowship awarded to M.A.R., a grant through Primate Conservation Inc., and a conservation grant through the International Primatological Society. It complied with animal care regulations and Indonesian laws.

Institutional Review Board Statement: This research complied with the protocols of University of Wisconsin-Madison's Institutional Animal Care and Use Committee of the Research Animal Resource Center (research exempt from protocol as a wildlife observational study), and the Institutional Review Board for human subjects research (protocol number SE-2008-0210). Our data collection complied with federal laws of Indonesia. Permits were obtained to enter and conduct research at the nature reserve Cagar Alam Leuweung Sancang from the Indonesian Forestry Department (\# SI 203; SI.1860/BBKSDA JABAR-2/2015), the Indonesian Department of Research and Technology (4000/SU/KS/2005; 1041/FRP/SM/VIII/2012; 921/FRP/SM/IIi/2013; and 238/SIP/FRP/SM/VIII/ 2015), and the Indonesian Police Department (\# 00-182620/p0/VII/2010). The research also adhered to the American Society of Primatologists Principles for the Ethical Treatment of Non-Human Primates.

Data Availability Statement: Not applicable.

Acknowledgments: We thank the Indonesian Department of Research and Technology (RISTEK) and the Indonesian Forestry Department (PHKA) for granting permission to conduct this research. We also thank our Indonesia sponsor, the environmental NGO KONUS and its director, Asep R. Purnama. We thank our Indonesian host family, the Haes family, for housing M.A.R. and her field assistants in Sancang, and Heri Octavinalis and Nissa Nuraini for sharing their home with her in Bandung. We would also like to thank all Indonesian field assistants: Ismail Agung, Wawan Tarwinan, Danius 'Ocoy' Tampubolon, Angga Kurniawan, Yadi Juned, and Soni Patinasarani. Expressions of gratitude are owed to the University of Colorado-Boulder for support during the final phase of manuscript completion.

Conflicts of Interest: The authors declare no conflict of interest. The funders had no role in the design of the study; in the collection, analyses, or interpretation of data; in the writing of the manuscript, or in the decision to publish the results.

\section{References}

1. Duchesne, M.; Cote, S.D.; Barrette, C. Responses of woodland caribou to winter ecotourism in the Charlevoix Biosphere Reserve, Canada. Biol. Conserv. 2000, 96, 311-317. [CrossRef]

2. Lott, D.F.; McCoy, M. Asian rhinos Rhinoceros unicornis on the run? Impact of tourist visits on one population. Biol. Conserv. 1995, 73, 23-26. [CrossRef] 
3. Rode, K.D.; Farley, S.D.; Fortin, J.; Robbins, C.T. Nutritional consequences of experimentally introduced tourism in brown bears. J. Wildl. Manag. 2007, 71, 929-939. [CrossRef]

4. Constantine, R. Increased avoidance of swimmers by wild bottlenose dolphins (Tursiops truncatus) due to long-term exposure to swim-with-dolphin tourism. Mar. Mammal Sci. 2001, 17, 689-702. [CrossRef]

5. Lusseau, D.; Higham, J.E.S. Managing the impacts of dolphin-based tourism through the definition of critical habitats: The case of bottlenose dolphins (Tursiops spp.) in Doubtful Sound, New Zealand. Tour. Manag. 2004, 25, 657-667. [CrossRef]

6. Müllner, A.; Eduard Linsenmair, K.; Wikelski, M. Exposure to ecotourism reduces survival and affects stress response in hoatzin chicks (Opisthocomus hoazin). Biol. Conserv. 2004, 118, 549-558. [CrossRef]

7. Skagen, S.K.; Knight, R.L.; Orians, G.H. Human disturbance of an avian scavenging guild. Ecol. Appl. 1991, 1, 215-225. [CrossRef] [PubMed]

8. Gerrodette, T.; Gilmartin, W.G. Demographic consequences of changing pupping and hauling sites of the Hawaiian monk seal. Conserv. Biol. 1990, 4, 423-430. [CrossRef]

9. Kappeler, M. The Javan Silvery Gibbon (Hylobates lar moloch). Ph.D. Thesis, Universitat Basel, Basel, Switzerland, 1981.

10. Bshary, R. Diana monkeys, Cercopithecus diana, adjust their anti-predator response behaviour to human hunting strategies. Behav. Ecol. Sociobiol. 2001, 50, 251-256. [CrossRef]

11. Nijman, V. Forest (and) Primates: Conservation and Ecology of the Endemic Primates of Java and Borneo; Tropenbos International: Amsterdam, The Netherlands, 2001.

12. Frid, A.; Dill, L.M. Human-caused disturbance stimuli as a form of predation risk. Conserv. Ecol. 2002, 6, 11-26. [CrossRef]

13. Stanford, C.B. Avoiding predators: Expectations and evidence in primate antipredator behavior. Int. J. Primatol. 2002, $23,741-757$. [CrossRef]

14. Croes, B.M.; Laurance, W.F.; Lahm, S.A.; Tchignoumba, L.; Alonso, A.; Lee, M.E.; Campbell, P.; Buij, R. The Influence of hunting on antipredator behavior in central African monkeys and duikers. Biotropica 2007, 39, 257-263. [CrossRef]

15. Miller, L.E.; Treves, A. Predation on primates: Past studies, current challenges, and directions for the future. In Primates in Perspective; Campbell, C.J., Fuentes, A., Mackinnon, K.C., Panger, M.A., Eds.; Oxford University Press: Oxford, UK, 2007 ; pp. $525-543$.

16. Grossberg, R.; Treves, A.; Naughton-Treves, L. The incidental ecotourist: Measuring visitor impacts on endangered howler monkeys at a Belizean archaeological site. Environ. Conserv. 2003, 30, 40-51. [CrossRef]

17. Treves, A.; Brandon, K. Tourist impacts on the behavior of black howling monkeys (Alouatta pigra) at Lamanai, Belize. In Commensalism and Conflict: The Human-Primate Interface; Pattterson, J.D., Wallis, J., Eds.; The American Society of Primatologists: Norman, OK, USA, 2005; pp. 146-166.

18. de la Torre, S.; Snowdon, C.T.; Bejarano, M. Effects of human activities on wild pygmy marmosets in Ecuadorian Amazonia. Biol. Conserv. 2000, 94, 153-163. [CrossRef]

19. Klailova, M.; Hodgkinson, C.; Lee, P.C. Behavioral responses of one western lowland gorilla (Gorilla gorilla gorilla) group at Bai Hokou, Central African Republic, to tourists, researchers and trackers. Am. J. Primatol. 2010, 72, 897-906. [CrossRef] [PubMed]

20. Johns, A.D. Behavioral responses of two Malaysian primates (Hylobates lar and Presbytis melalophos) to selective logging: Vocal behavior, territoriality, and nonemigration. Int. J. Primatol. 1985, 6, 423-433. [CrossRef]

21. Johns, A.D. Effects of selective logging on the behavioral ecology of West Malaysian primates. Ecology 1986, 67, 684-694. [CrossRef]

22. Brown, J.S.; Morgan, R.A. Effects of foraging behavior and spatial scale on diet selectivity: A test with fox squirrels. Oikos 1995, 74, 122-136. [CrossRef]

23. Sinclair, A.R.E.; Arcese, P. Population consequences of predation sensitive foraging: The Serengeti wildebeest. Ecology 1995, 76, 882-891. [CrossRef]

24. Ruxton, G.D.; Lima, S.L. Predator-induced breeding suppression and its consequences for predator-prey population dynamics. Proc. R. Soc. B Biol. Sci. 1997, 264, 409-415. [CrossRef]

25. Schmitz, O.J.; Beckerman, A.P.; O’Brien, K.M. Behaviorally mediated trophic cascades: Effects of predation risk on food webs. Ecology 1997, 78, 1388-1399. [CrossRef]

26. Brown, J.H.; Ernest, S.K.M. Rain and rodents: Complex dynamics of desert consumers. BioScience 2002, 52, 979-987. [CrossRef]

27. Ripple, W.J.; Beschta, R.L. Wolves and the ecology of fear: Can predation risk restructure ecosystems. Bioscience 2004, 54, 755-766. [CrossRef]

28. Berger, J. Fear, human shields, and the redistribution of prey and predators in protected areas. Biol. Lett. 2007, 3, 620-623. [CrossRef]

29. Berger, J. The Better to Eat You with: Fear in the Animal World; University of Chicago Press: Chicago, IL, USA, 2008.

30. Brown, J.S.; Kotler, B.P. Foraging and the ecology of fear. In Foraging: Behavior and Ecology; Stephens, D.W., Brown, J.S., Ydenberg, R.C., Eds.; University of Chicago Press: Chicago, IL, USA, 2007; pp. 437-482.

31. Creel, S.; Christianson, D.; Liley, S.; Winnie, J.A. Predation risk affects reproductive physiology and demography of elk. Science 2007, 315, 960. [CrossRef] [PubMed]

32. Middleton, A.D.; Kauffman, M.J.; McWhirter, D.E.; Jimenez, M.D.; Cook, R.C.; Cook, J.G.; Albeke, S.E.; Sawyer, H.; White, P.J. Linking anti-predator behavior to prey demography reveals limited risk effects of an actively hunting large carnivore. Ecol. Lett. 2013, 16, 1023-1030. [CrossRef]

33. Brown, J.S.; Alkon, P.U. Testing values of crested porcupine habitats by experimental food patches. Oecologia 1990, 83, 512-518. [CrossRef]

34. Creel, S.; Christianson, D. Relationships between direct predation and risk effects. Trends Ecol. Evol. 2008, 23, 194-201. [CrossRef] 
35. Bejder, L.; Samuels, A.; Whitehead, H.; Gales, N. Interpreting short-term behavioural responses to disturbance within a longitudinal perspective. Anim. Behav. 2006, 72, 1149-1158. [CrossRef]

36. Strier, K.B. Demography and conservation of an endangered primate, Brachyteles arachnoids. Conserv. Biol. 1991, 5, 214-218. [CrossRef]

37. Strier, K.B. Population viabilities and conservation implications for muriquis (Brachyteles arachnoids) in Brazil's Atlantic forest. Biotropica 2000, 32, 903-913.

38. Strier, K.B.; Boubli, J.P.; Possamai, C.B.; Mendes, S.L. Population demography of northern muriquis (Brachyteles hypoxanthus) at the Estação Biológica de Caratinga/Reserva particular do Patrimônio Natural-Felìciano Miguel Abdala, Minas Gerais, Brazil. Am. J. Phys. Anthropol. 2006, 130, 227-237. [CrossRef]

39. Cowlishaw, G.; Dunbar, R. Primate Conservation Biology; University of Chicago Press: Chicago, IL, USA, 2000.

40. Embassy of Indonesia, Ottawa. Available online: http:/ / www.indonesia-ottawa.org/ (accessed on 1 January 2008).

41. Wessing, R. A change in the forest: Myth and history in West Java. J. Southeast Asian Stud. 1993, 24, 1-17. [CrossRef]

42. Geertz, C. Agricultural Involution: The Process of Ecological Change in Indonesia; University of California Press: Berkeley, CA, USA, 1963.

43. Nijman, V. Conservation of the Javan gibbon Hylobates moloch: Population estimates, local extinctions, and conservation priorities. Raffles Bull. Zool. 2004, 52, 271-280.

44. Malone, N.M. The Socioecology of the Critically Endangered Javan Gibbon (Hylobates moloch): Assessing the Impact of Anthropogenic Disturbance on Primate Social Systems. Ph.D. Thesis, University of Oregon, Eugene, OR, USA, 2007.

45. Malone, N.M.; Fuentes, A.; Purnama, A.R.; Wedana, I. Displaced hylobatids: Biological, cultural, and economic aspects of the primate trade in Jawa and Bali, Indonesia. Trop. Biodivers. 2003, 8, 41-50.

46. Andayani, N.; Brockelman, W.; Geissmann, T.; Nijman, V.; Supriatna, J. Hylobates moloch. IUCN 2012. IUCN Red List of Threatened Species. Version 2012.2. Available online: www.iucnredlist.org (accessed on 18 January 2013).

47. Supriatna, J.; Mootnick, A.; Andayani, N. Javan gibbon (Hylobates moloch): Population and conservation. In Indonesian Primates; Gursky, S., Supriatna, J., Eds.; Springer: New York, NY, USA, 2010; pp. 57-72.

48. Supriatna, J. Conservation programs for the endangered Javan gibbon (Hylobates moloch). Primate Conserv. 2006, $21,155-162$. [CrossRef]

49. Nijman, V. In Full Swing. An Assessment of the Trade in Gibbons and Orangutans on Java and Bali, Indonesia; TRAFFIC South-east Asia: Kuala Lumpur, Malaysia, 2005.

50. Wedana, A.P.I.M.; Jeffery, S. Reinforcing the Javan silvery gibbon population in the Mount Tilu Nature Reserve, West Java, Indonesia. In Proceedings of the Programme of the XXVIth Congress of the International Primatological Society, Chicago, IL, USA, 21-27 August 2016.

51. Lebbie, A.R.; Freudenberger, M. Sacred groves in Africa: Forest patches in transition. In Forest Patches in Tropical Landscapes; Shelhas, J., Greenberg, R., Eds.; Island Press: Washington, DC, USA, 1996; pp. 300-324.

52. Reisland, M.A. Conservation in a Sacred Forest: An Integrated Approach to Assessing the Management of a Community-Based Conservation Site. Ph.D. Thesis, University of Wisconsin, Madison, WI, USA, 2013.

53. Malone, N.; Wade, A.; Putra, M.W.A.; Reisland, M.; Selby, M. Calibrating a conservation strategy for silvery gibbons (Hylobates moloch). Am. J. Phys. Anthropol. 2012, 147, 202.

54. Malone, N.; Wedana, M. Struggling for socio-ecological resilience: A long-term study of silvery gibbons (Hylobates moloch) in the fragmented Sancang Forest Nature Reserve, West Java, Indonesia. In Primate Research and Conservation in the Anthropocene; Behie, A., Teichroeb, J., Malone, N., Eds.; Cambridge University Press: Cambridge, UK, 2019; pp. 17-32.

55. Cybertracker2010. Available online: http:/ / www.cybertracker.org (accessed on 15 June 2010).

56. Martin, P.; Bateson, P. Measuring Behavior: An Introductory Guide, 2nd ed.; Cambridge University Press: Cambridge, UK, 1993.

57. Holm, S. A simple sequentially rejective multiple test procedure. Scand. J. Stat. 1979, 6, 65-70.

58. Bejder, L.; Samuels, A.; Whitehead, H.; Finn, H.; Allen, S. Impact assessment research: Use and misuse of habituation, sensitisation and tolerance in describing wildlife responses to anthropogenic stimuli. Mar. Ecol. Prog. Ser. 2009, 395, 177-185. [CrossRef]

59. Gill, J.A.; Sutherland, W.J. Predicting the consequences of human disturbance from behavioural decisions. In Behaviour and Conservation; Gosling, L.M., Sutherland, W.J., Eds.; Cambridge University Press: Cambridge, UK, 2000; pp. 51-64.

60. Kappeler, M. Vocal bouts and territorial maintenance in the moloch gibbon. In The Lesser Apes. Evolutionary and Behavioural Biology; Preuschoft, H., Chivers, D.J., Brockelman, W.Y., Creel, N., Eds.; Edinburgh University Press: Edinburgh, UK, $1984 ;$ pp. 376-389.

61. Geissmann, T.; Nijman, V. Calling in wild silvery gibbons (Hylobates moloch) in Java (Indonesia): Behavior, phylogeny, and conservation. Am. J. Primatol. 2006, 68, 1-19. [CrossRef]

62. Mitani, J.C. The behavioral regulation of monogamy in gibbons (Hylobates muelleri). Behav. Ecol. Sociobiol. 1984, 15, 225-229. [CrossRef]

63. Mitani, J.C. Gibbon song duets and intergroup spacing. Behaviour 1985, 92, 59-96. [CrossRef]

64. Mitani, J.C. Location-specific responses of gibbons (Hylobates muelleri) to male songs. Z. Tierpsychol. 1985, 70, 219-224. [CrossRef]

65. Mitani, J.C. Territoriality and monogamy among agile gibbons (Hylobates agilis). Behav. Ecol. Sociobiol. 1987, 20, 265-269. [CrossRef]

66. Raemaekers, J.J.; Raemaekers, P.M. Field playback of loud calls to gibbons (Hylobates lar): Territorial, sex-specific and speciesspecific responses. Animal Behav. 1985, 33, 481-493. [CrossRef]

67. Raemaekers, P.M.; Raemaekers, J.J. Long-range vocal interactions between groups of gibbons (Hylobates lar). Behaviour 1985, 95, 26-44. [CrossRef] 
68. Leighton, D.R. Gibbons: Territoriality and monogamy. In Primate Societies; Smuts, B.B., Cheney, D.L., Seyfarth, R.M., Wrangham, R.W., Struhsaker, T.T., Eds.; University of Chicago Press: Chicago, IL, USA, 1987; pp. 135-145.

69. Cowlishaw, G. Song function in gibbons. Behaviour 1992, 121, 131-153. [CrossRef]

70. Geissmann, T. Duet songs of the siamang, Hylobates syndactylus: II. Testing the pair-bonding hypothesis during a partner exchange. Behaviour 1999, 136, 1005-1039. [CrossRef]

71. Geissmann, T.; Orgeldinger, M. The relationship between duet songs and pair bonds in siamangs, Hylobates syndactylus. Anim. Behav. 2000, 60, 805-809. [CrossRef]

72. Krüger, O. The role of ecotourism in conservation: Panacea or Pandora's box? Biodivers. Conserv. 2005, 14, 579-600. [CrossRef]

73. Ferguson, M.A.D.; Keith, L.B. Influence of Nordic skiing on distribution of moose and elk in Elk Island National Park, Alberta. Can. Field-Nat. 1982, 96, 69-78.

74. Lippold, L.K. Primate population decline at Cabo Blanco Absolute Nature Reserve, Costa Rica. Brenesia 1990, 34, 145-152.

75. Cassirer, E.F.; Freddy, D.J.; Ables, E.D. Elk responses to disturbance by cross-country skiers in Yellowstone National Park. Wildl. Soc. Bull. 1992, 20, 375-381.

76. Beier, P. Dispersal of juvenile cougars in fragmented habitat. J. Wildl. Manag. 1995, 59, 228-237. [CrossRef]

77. McNeilage, A. Ecotourism and mountain gorillas in the Virunga volcanoes. In The Exploitation of Mammal Populations; Taylor, V.J., Dunstone, N., Eds.; Chapman \& Hall: London, UK, 1996; pp. 334-344.

78. Gander, H.; Ingold, P. Reactions of male alpine chamois Rupicapra r. rupicapra to hikers, joggers, and mountainbikers. Biol. Conserv. 1997, 79, 107-109. [CrossRef]

79. Buckley, R. Impacts of ecotourism on terrestrial wildlife. In Environmental Impacts of Ecotourism; Buckley, R., Ed.; CABI Publishing: Cambridge, UK, 2004; pp. 211-228.

80. Reisland, M.A.; Lambert, J.E. Sympatric apes in sacred forests: Shared space and habitat use by humans and endangered Javan gibbons (Hylobates moloch). PLoS ONE 2016, 11, e0146891. [CrossRef] 